Human Resource and

Leadership Journal

(HRL)

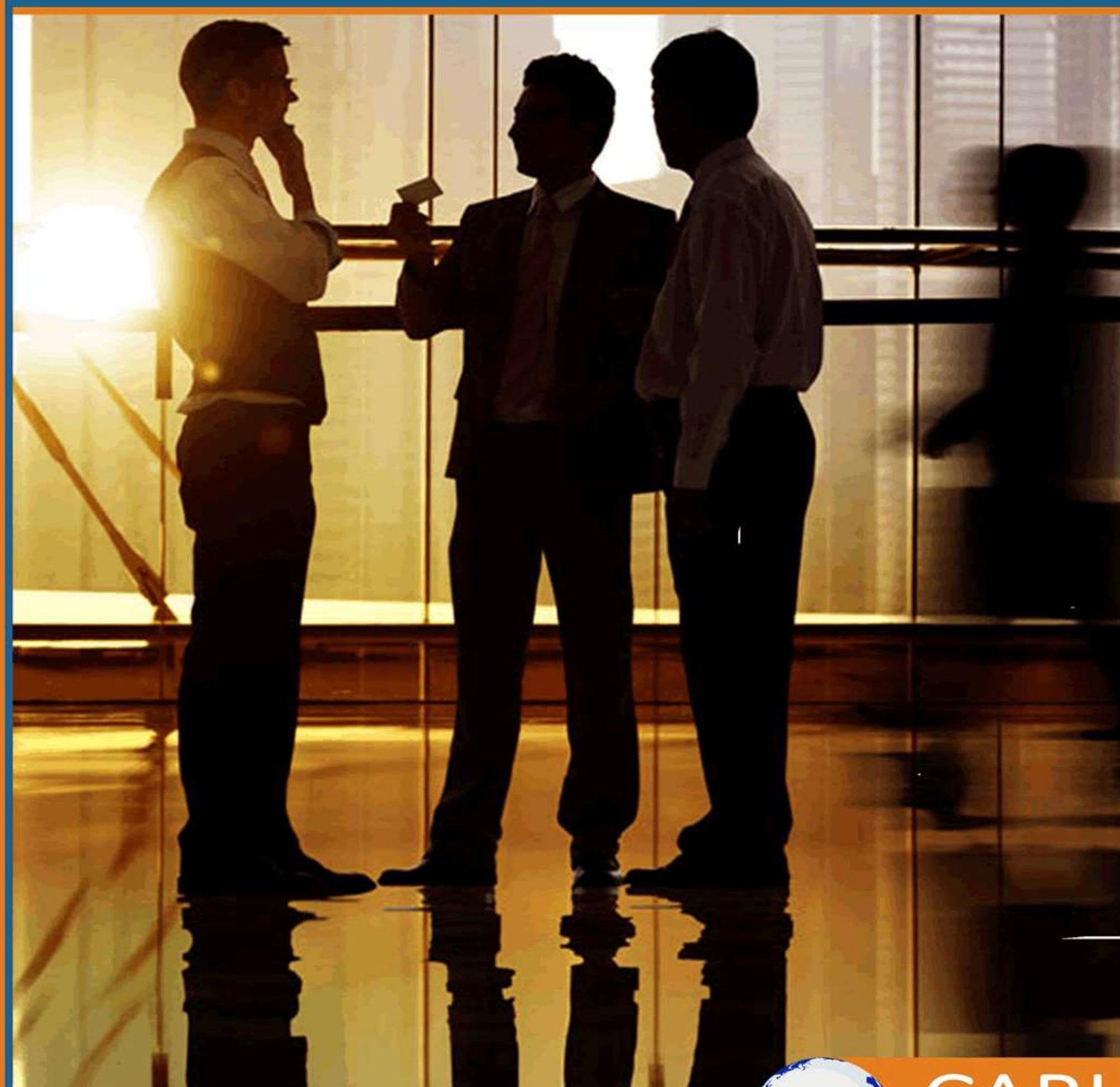




\title{
EFFECT OF IDEALIZED INFLUENCE AND INSPIRATIONAL MOTIVATION ON JOB SATISFACTION AMONG EMPLOYEES IN COMMERCIAL BANKS IN KENYA
}

\author{
${ }^{*}$ Njiinu Andrew Njiraini, \\ ${ }^{1}$ Research Scholar : United States International University-Africa \\ *Corresponding Email: andrewnjiraini@gmail.com \\ ${ }^{2}$ Prof. George O. K'Aol \\ Senior Lecturer: United States International University-Africa, \\ P.O. Box, 14634 - 00800 Nairobi, Kenya \\ Email: gkaol@usiu.ac.ke \\ ${ }^{3}$ Prof. Teresia K. Linge \\ Senior lecturer : United States International University-Africa, \\ P.O. Box, 14634 - 00800 Nairobi, Kenya \\ Email: tlinge@usiu.ac.ke
}

\begin{abstract}
Purpose: The purpose of the study was to determine the extent to which idealized influence and inspirational motivation influence job satisfaction among employees in commercial banks in Kenya.

Methodology: The study adopted a positivism research philosophy and a descriptive correlation research design. The target population consisted of 10,310 managerial employees in the commercial banks in Kenya. A sample of 424 employees was obtained from the population using stratified random sampling technique. Data was collected using structured questionnaires. A response rate of $82 \%$ was obtained. Data was analyzed using descriptive statistics and inferential statistics. Inferential statistical methods used to analyze the data were Chi-square, Pearson's correlation, ANOVA, and multiple linear regressions. The Statistical Package for Social Sciences (SPSS) tool version 22 was used to analyze the data.

Findings: Correlation analysis found that idealized influence, inspirational motivation and job security were positively and significantly correlated to job satisfaction $r(346)=.496, p<.05, r$ $(347)=.587, p<.05, r(347)=.697, p<.05$ respectively. Multiple linear regression results showed that idealized influence significantly influenced job satisfaction of the employees $\left(\mathrm{R}^{2}=.246\right.$, $F(1,97.750)=112.421, p<.05)$.Similarly, multiple linear regression results showed that inspirational motivation significantly influenced job satisfaction of the employees $\left(\mathrm{R}^{2}=.344\right.$, $F(1,126.302)=180.980, \mathrm{p}<.05)$.
\end{abstract}


Human Resource and Leadership Journal

ISSN 2520-4661 (Online)

Vol.3, Issue No.1, p 23 - 46, 2018

$\underline{\text { www.carijournals.org }}$

Job security was found to significantly moderate the relationships between idealized influence, inspirational motivation and job satisfaction $\left(\mathrm{R}^{2}=.431, F(3,44.688)=86.330, p<.05\right)$.

Unique contribution to the theory, practice and policy: Previous studies on transformational leadership have focused mainly on transformational leadership and employee performance. The unique contribution of this study is the advancement of transformational leadership theory dimensions - idealized influence and inspirational motivation - and job satisfaction among employees in commercial Banks in Kenya. The recommendations of this study contribute to practice of leadership in the commercial banks in Kenya by providing tools that enhance job satisfaction. Lastly, the findings inform organizational polices touching on leadership and job satisfaction.

Key Words: Transformational leadership, idealized influence, inspirational motivation, job security, job satisfaction

\subsection{INTRODUCTION}

\subsection{Background of the Study}

An organization's success largely depends on the leadership style of the management. Organizational success is characterized by employee job satisfaction and employee affective commitment (Abouraia \& Othman, 2017). This is achieved through effective leadership which precipitates the attainment of employee motivation and clear understanding of the organization's objectives. To enhance job satisfaction scholars have argued that leadership must provide motivation, inspiration and good remuneration to the employees, all of which have a combined effect of low attrition rates and decreased absenteeism (Hurduzeu, 2015). Transformational leadership style helps to create employee job satisfaction and commitment to the organization (Patiar \& Wang, 2016). Leadership style is therefore an antecedent of job satisfaction and is considered a predictor of job satisfaction (Munir, Rahman, Malik \& Ma'amor, 2012; Long, Yusuf, Kowang \& Heng 2014).

Banks play a critical role in an economy and are crucial in ensuring economic stability and growth. They act as the lifeline of modern trade and commerce by providing finance and payments infrastructure (Akotch \& Munyoki, 2016). In economic development, they also support development of new businesses hence creating the employment opportunities whilst catalyzing economic growth (Arif \& Anees, 2012). During the financial crisis a few years ago, many financial institutions were exposed and there were demands from stakeholders to improve performance by adopting new management practices to strengthen their capital, reduce nonperforming loans, reduce costs, improve corporate governance and come up with customer focused products (Munir, Baird \& Perera, 2013). This has yielded new rules, regulations and guidelines from the various country regulators and the world financial systems all of which affect the employee's attitudes, behaviors and ultimately job satisfaction levels (Sattar \& Ali, 2014). In Kenya, the sector is changing at a very fast pace calling for a lot of dynamism not only in areas that contribute to profitability but also in policies regarding employee's welfare and job satisfaction because they are the greatest assets the banks have (Njuguna \& Owuor, 2016). 
Human Resource and Leadership Journal

ISSN 2520-4661 (Online)

Vol.3, Issue No.1, p 23 - 46, 2018

www.carijournals.org

\subsection{Statement of the Problem}

Leadership plays a significant role when dealing with employees. Specific variables like job satisfaction have gained prominence in the contemporary era and have become important areas for organizations (Malik, Javed \& Hassan, 2017). Banks are very important institutions in any economy because of the significant role they play by offering financial services. Many economies have gone through financial crises which have resulted in far reaching effects on many banks globally. These effects have significantly affected the employees' levels of job satisfaction. As a result, these institutions are in need of leadership that will ensure there is sustained job satisfaction among the employees because such periods of crisis result into negative defensive behavior and attitudes which result from uncertainty; all of which affect job satisfaction (Belias \& Koustelious, 2014). Organizations lack adequate human resource management policies geared towards job satisfaction (Saner \& Eyupoglu, 2015).Tetteh and Brenyah (2016), in their study found that transformational leadership increased employee job satisfaction among employees in telecommunication sector in Ghana. They recommended that further studies be carried out in sectors like banking with results aimed at providing knowledge in that will help address issues of job satisfaction.

\subsection{Purpose of the Study}

The purpose of the study was to examine the extent to which idealized influence and inspirational motivation influence job satisfaction among employees in commercial banks in Kenya.

\subsection{Research Questions}

This study was guided by the following research questions:

1.4.1 To what extent does idealized influence affect job satisfaction among employees in commercial banks in Kenya?

1.4.2 To what extent does inspirational motivation influence job satisfaction among employees in commercial banks in Kenya?

1.4.3 To what extent does job security moderate the relationship between idealized influenced, inspirational motivation and job satisfaction among employees in commercial banks in Kenya?

\subsection{Research Hypotheses}

The following null hypotheses were used to determine effect of idealized influence and inspirational motivation on job satisfaction among employees in commercial banks in Kenya:

$\mathbf{H}_{01}$ : There is no significant influence of idealized influence on job satisfaction among employees in commercial banks in Kenya

$\mathbf{H}_{02}$ : There is no significant influence of inspirational motivation on job satisfaction among employees in commercial banks in Kenya

$\mathbf{H}_{03}$ : There is no significant moderating effect of job security between idealized influenced, inspirational motivation and job satisfaction among employees in commercial banks in Kenya 
Human Resource and Leadership Journal

ISSN 2520-4661 (Online)

Vol.3, Issue No.1, p 23 - 46, 2018

$\underline{\text { www.carijournals.org }}$

\subsection{THEORETICAL AND EMPIRICAL REVIEW}

\subsection{Theoretical Review}

The study was underpinned by the transformational leadership theory. Transformational leadership theory was first articulated by Burns in the year 1978 (Burns, 1978). The transformational leadership theory was then advanced by Bernard Bass almost ten years after Burns had brought it up. The theory postulates that the leader must clearly communicate the organization vision, enhance individual mind development and motivate the employee's desire to be associated with organization development. Bass (1985) argued that through transformational leadership all followers are involved in pursuit of organization goals. Transformational leadership is classified into four dimensions which are idealized influence, inspiration motivation, intellectual simulation and individual consideration. Idealized influence is the capability of a leader to exert influence by serving as a role model through demonstration of high performance and moral standards. By this, the leaders persuade the followers to share in the organization's vision and objectives (Muenjohn, 2010). Some attributes to idealized influence are vision, trust, respect, integrity and modeling. Idealized influence enables a leader to become a role model and gains respect from the followers. Through charismatic influence, a leader is able to instill pride, attract faith and respect from the followers and makes them to see the bigger picture thereby establishing a common mission. This enables performance to rise beyond expectations and produces energy for achieving high work objectives (Brandt, Laitinen \& Laitinen, 2016). Inspirational motivation is the ability of a leader to behave in a way that motivates the followers, generates enthusiasm and challenges people. Leaders do this when they develop and communicate a convincing and an attractive future vision and also when they clearly communicate the expectations. Leaders are able to motivate the followers through a compelling vision for the future and by expressing confidence in the followers. It is also a function of leaders expressing high expectations of the followers to achieve extra ordinary achievements and at the same time displaying confidence in their potential. Inspirational motivation could easily overlap with charisma but it is worth noting that inspirational motivation could occur without a need for identifying with the leader which is the case for charismatic leaders (Muenjohn, 2010).

\subsection{Conceptual Framework}

The conceptual framework for this study was informed by the transformational leadership theory. This study sought to establish the effect of idealized influence and inspirational motivation on job satisfaction among employees in commercial banks in Kenya. The study had two independent variables which were idealized influence and inspirational motivation. Idealized influence was studied through charisma, trust and ethics which were found to be adequate variables of measure. Inspirational motivation was studied through communication, teamwork and motivation which were also found to be adequate measures. The dependent variable was job satisfaction which was measured using organizational commitment, absenteeism and turnover intentions which suitable measures. The relationship between the independent variables and the dependent variable was moderated by job security which was measured using fairness, anxiety and stress. The conceptual framework is presented in figure 1 . 


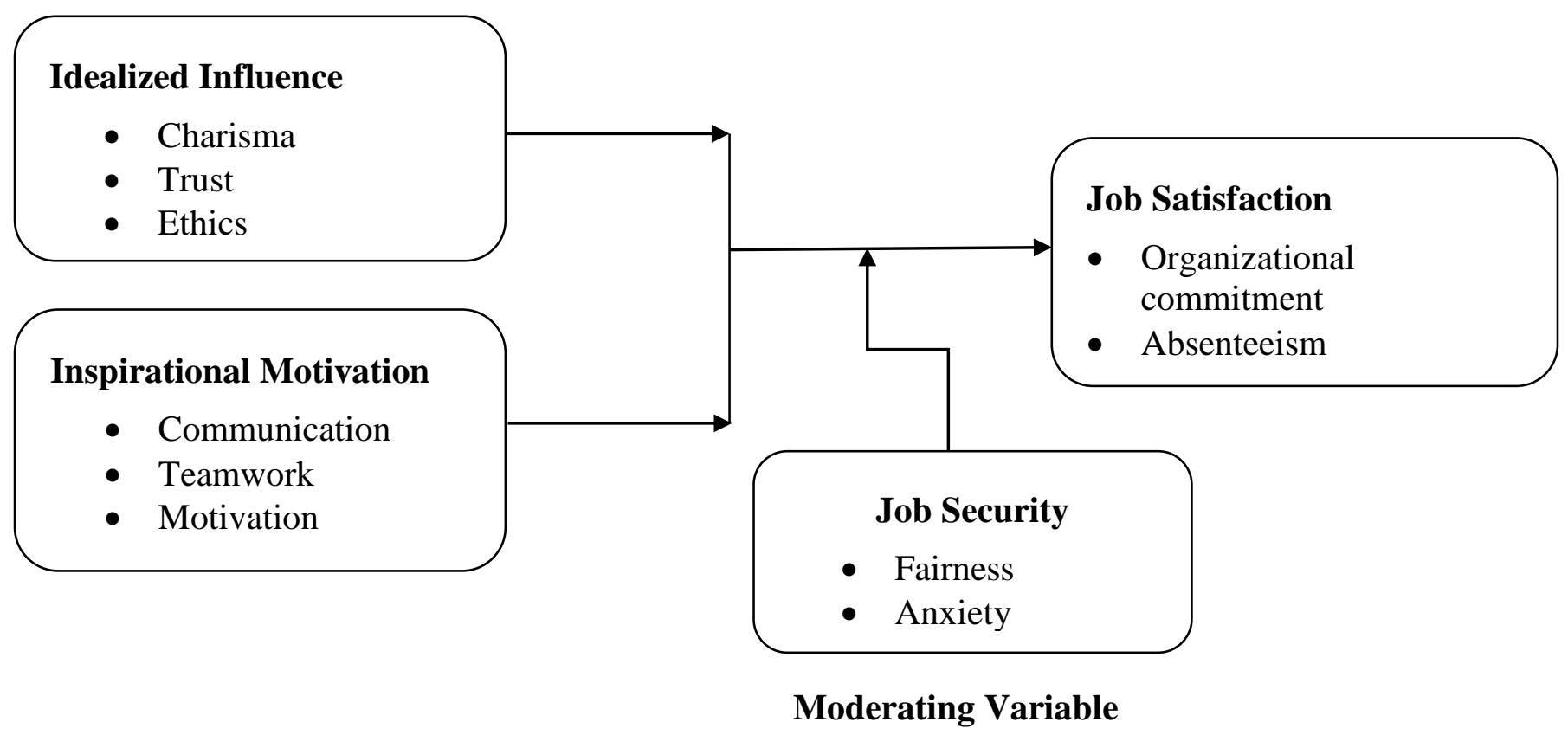

Figure 1: Conceptual Framework

\subsection{Empirical Review}

This section comprises of the empirical review for idealized influence, inspirational motivation, job security and job satisfaction.

\subsubsection{Idealized Influence on Job Satisfaction}

Idealized influence is one of the tenets of transformational leadership that determines the effectiveness of transformational leadership. Leaders use idealized influence to exert influence by being role models, demonstrating high performance, being trustworthy as well as ethical (Omar \& Hussin, 2013). Idealized influence results from the leader's behaviour, beliefs, moral standards and conformity of values (Avolio \& Bass, 2002). Bell (2013), referred to charisma as an untraditional form of influence where the leader has exceptional qualities which are perceived by his followers. Previous studies have found a positive relationship between charisma and job satisfaction which was statistically insignificant (Hanaysha et al., 2012; Khuong \&Hoang, 2015). An ethical climate refers to individual beliefs about the organizational practices, procedures, standards and ethical values. An ethical climate in organizations has been associated with enhanced levels of satisfaction by the employees (Ahmed et al., 2012).. Additionally, research posits that organizational outcomes can be influenced by leaders support and reward of ethical behavior (Awasthi, 2015). Dinc and Aydemir (2014) found a positive correlation between an ethical climate and job satisfaction among employees in Bosnia. 
Human Resource and Leadership Journal

ISSN 2520-4661 (Online)

Vol.3, Issue No.1, p 23 - 46, 2018

A further analysis indicated that there was a positive correlation between the employee's perception of ethics in the organization and job satisfaction which results in reduced turnover intentions from the employees (Pettijohn, Pettijon \& Taylor, 2008).Interpersonal trust has been described as a social lubricant which helps to facilitate collective efforts and perceptions within an organization (Kelly, Lercel \& Patankar, 2015). Organizational trust is a general organizing principle; thus the foundation of a general governing system of the contractual relations which can be invoked to control opportunism, costs and monitor problems in organizations. It has been argued that organizational trust enhances job satisfaction and also job satisfaction enhances organizational trust (Mincu, 2015; Usikalu, Ogunleye \& Effiong, 2015). Studies have found a positive effect of idealized influence on job satisfaction (Gitoho, Muchara \& Ngugi, 2016; Emu \&Umeh, 2014). Long et al. (2014) examined the impact of transformational leadership on job satisfaction in Malaysia. Correlation and regression tests revealed a positive but non-significant relationship between idealized influence and job satisfaction.

\subsubsection{Influence of Inspirational Motivation on Job Satisfaction}

Inspirational motivation enables leaders to communicate high expectations to the teams which inspire them through motivation to own and become part of the organization vision(Tetteh \& Brenyah, 2016).Ngaithe, K'Aol, Lewa and Ndwiga (2016) noted that communication is one of the key elements of inspirational motivation. Employee perception of top management openness in communication influences the overall job satisfaction (Winska, 2010). Akipinar et al. (2013) conducted a study to establish the effect of organizational communication and job satisfaction on organizational commitment in small businesses. The results indicated there was a positive relationship between employee's perception of organizational communication and organizational commitment which is a measure of job satisfaction. Teamwork has a positive impact on achievement of job efficiency and enhancing the productivity of organizations. Research has indicated that teamwork reduces human errors due to complimentary skills, enhanced performance and promotes job satisfaction of employees (Benrazavi \& Silong, 2013). Through teamwork, employees are able to achieve more through collaboration, enhance their knowledge and skills. Research goes on to indicate that organizations that encourage teamwork are more likely to retain good talent (Manzoor, Ullah, Hussain \& Ahmad, 2011). Rana (2015) found that teamwork significantly influenced job satisfaction. Shujaat, Manzoor and Syed (2014), conducted a research to establish the impact of team work on employee job satisfaction. Results of the study indicated there is a significant impact between team work and job satisfaction. Motivation refers to the psychological processes that determine the onset, directing and maintaining voluntary actions towards organizational goals. It is a critical factor in organizations because it is a factor which significantly influences job satisfaction and job performance (Rajan, 2015). A motivated employee feels satisfied with their job and is empowered to strive for excellence and growth. Motivation boosts commitment and satisfaction with the job and yields in greater productivity. Research notes there is a significant difference between the productivity of motivated employees and non-motivated employees (Osakwe, 2014).Additionally, there are the intrinsic motivators and extrinsic motivators and it was found that there is a significant positive correlation between intrinsic motivators and job satisfaction in banks in India (Chatterjee \& Chattopadhyay, 2015). 
Human Resource and Leadership Journal

ISSN 2520-4661 (Online)

Vol.3, Issue No.1, p 23 - 46, 2018

$\underline{\text { www.carijournals.org }}$

\subsubsection{Moderating Effect of Job Security on the effect of Idealized Influence and Inspirational Motivation and Job Satisfaction}

Job security refers to one's expectations regarding the continuity in a job situation. Job security goes over and above the loss or retention of a job to the continuation or loss of certain desirable job features such as promotion opportunities, favorable working condition and long term growth opportunities with the organization (Akpan, 2013). Job security is a key factor that influences the employee's perception of job (Alonderiene \& Majauskaite, 2016). Anxiety manifests itself through future concerns and the inability to predict that future. Studies have found these elements to be strong predictors of job satisfaction and thus a leader should endeavor to reassure his employees through effective and accurate communication to dismay any anxieties for there to be job satisfaction (Kler, Leeves \& Shankar, 2015). Poursadeghiyan et al. (2016) found that stress was a big contributor to anxiety and this was negatively associated with depression and job satisfaction. Zalewska (2011), also agrees with the findings that job anxiety is negatively correlated with the level of job satisfaction from their study carried out among 240 employees.Imran, Majeed and Ayub (2015), examined the relationship between organizational justices, job security, and job satisfaction on organizational productivity in Pakistan. The study found a positive and significant relationship between job security and job satisfaction. Susanj and Jakopec (2012), in their study exploring the role of justice perceptions and job satisfaction conclude that employee job satisfaction depends on the perceived justice levels in the organization. Rai (2013) found that perceived justice influenced job satisfaction, organizational commitment and the intention to leave. Khan, Ramzan and Butt (2013), sought to determine whether job satisfaction of Islamic banks operational staff was determined through organizational climate, occupational stress, age and gender. The results reveal that organizational climate and occupational stress have a significant impact on level of job satisfaction. Lin, Bahron and Boroh (2014) found a significant relationship between role stress and job satisfaction among bank employees in Malaysia. Iqbal and Waseem (2012) found a negative relationship between job stress and job satisfaction among air controllers in Pakistan.

\subsection{RESEARCH METHODOLOGY}

\subsection{Research Philosophy and Research Design}

The study adopted a positivism research philosophy and a descriptive correlation research design. Positivism philosophical approach contends that reality is stable, can be observed and described objectively. Positivism research philosophy was adopted because it is suitable for quantitative research. The descriptive correlational research design was adopted because the research was quantitative in nature and was aimed testing hypotheses.

\subsection{Target Population and Sampling Design}

The target population consisted of 10,310 managerial employees in the commercial banks in Kenya. The target population consisted of managerial employees because they mostly experienced the leadership style of the chief executive. A sample size of 385 was obtained from the population using stratified random sampling technique. Ten percent was added to the sample size to cater for non-respondents. Stratified random sampling was adopted because the commercial banks in Kenya are stratified into three tiers by the Central Bank of Kenya. 
Human Resource and Leadership Journal

ISSN 2520-4661 (Online)

Vol.3, Issue No.1, p 23 - 46, 2018

www.carijournals.org

\subsection{Data Collection and Analysis}

Data was collected using structured questionnaires. The questionnaires had six sections: one section on demographic and general information, four sections on the research questions and the last one on the moderating variable. A pilot study was conducted to test reliability and validity of the data collection instrument. A Cronbach Alpha of 0.978 was obtained which indicated the data collection instrument was reliable. A response rate of $82 \%$ was obtained. Data analysis was conducted using both descriptive statistics and inferential statistics. The inferential statistical methods used to analyze the data were Chi-square, Pearson's correlation, ANOVA, and multiple linear regression. Factor analysis was also done to ensure that the questions related to the construct of measure. The Statistical Package for Social Sciences (SPSS) tool version 22 was used to analyze the data.

\subsection{RESULTS AND FINDINGS}

\subsection{Demographic Information}

The results on demographic information revealed that $52 \%$ of the respondents were male and $48 \%$ were female which revealed a balance in gender among the employees. The results also indicated that about $97 \%$ of the respondents were aged between 21 years and 49 years. The age bracket with the highest percentage of employees was 30-39 years which had 49\%. These indicated that the banks preferred having a young workforce. The results further showed that $59 \%$ of the respondents had a bachelor's degree and about 33\% had master's degrees. This indicated that there were not much educational requirements in the banks. The respondents were comprised of $49 \%$ tier $1,34 \%$ tier 2 and $17 \%$ tier 3 banks. This was because tier 1 comprised of the larger banks and tier 3 composed of the smaller banks. The results are presented in Table 1. 
Human Resource and Leadership Journal

ISSN 2520-4661 (Online)

Vol.3, Issue No.1, p 23 - 46, 2018

www.carijournals.org

Table 1: Demographic Results

\begin{tabular}{|l|l|}
\hline Demographic Variables & Results \\
\hline Gender of the respondents & $\begin{array}{l}\text { Male }=52 \% \\
\text { Female }=48 \%\end{array}$ \\
\hline Age of the respondents & $\begin{array}{l}21-29 \text { years }=35.2 \% \\
30-39 \text { years }=48.5 \% \\
40-49 \text { years }=13.1 \%\end{array}$ \\
$50-59$ years $=2.9 \%$ \\
Ever 60 years $=0.3 \%$
\end{tabular}

4.2 Idealized Influence

\subsubsection{Chi-square Test: Idealized Influence and Job Satisfaction}

The Chi-square test was conducted to determine whether there was an association between idealized influence and job satisfaction. The Chi-square test results showed that idealized influence and job satisfaction were strongly associatedX $\left.{ }^{2}(132, \mathrm{~N}=346)=302.886, p<.05\right)$. This indicated that idealized influence was likely to improve job satisfaction among employees in commercial banks in Kenya. 
Human Resource and Leadership Journal

ISSN 2520-4661 (Online)

Vol.3, Issue No.1, p 23 - 46, 2018

www.carijournals.org

\subsubsection{Correlation between Idealized Influence and Job Satisfaction}

Correlation analysis was used to determine the relationship between idealized influence and job satisfaction. The results showed that there was a strong and positive correlation between idealized influence and job satisfaction $r(346)=.496, p<.05$ as presented in Table 2.

Table 2: Correlation Analysis on Idealized Influence and Job Satisfaction

\begin{tabular}{|l|l|l|}
\hline \multicolumn{2}{|l|}{ Idealized influence } & Job Satisfaction \\
\cline { 2 - 3 } & Pearson Correlation & $.496^{* *}$ \\
\cline { 2 - 3 } & Sig. (2-tailed) & $\mathbf{. 0 0 0}$ \\
\cline { 2 - 3 } & $\mathrm{N}$ & 346 \\
\hline
\end{tabular}

\subsubsection{One Way ANOVA on Idealized Influence}

The one way ANOVA test was conducted to test whether there were differences in the mean of idealized influence and the demographic information of respondents; gender, age, education level, duration of working at the bank and the tier of the bank. The results indicated there was no significant difference between the mean values of all the respondents' demographic information and idealized influence. The results found no significant differences in the mean for idealized influence across the managers demographic variables: gender, $F(11,332)=1.388, p<.05$; age, $F$ $(11,331)=1.514, p<.05$; education level, $F(11,332)=1.144, p<.05$; duration of working, $F$ $(11,332)=1.031, p<.05$; and lastly tier of the bank, $F(11,334)=1.686, p<.05$.

\subsubsection{Regression Analysis and Hypothesis Testing on Idealized influence}

Regression analysis was conducted to test the hypothesis. The model summary shows how idealized influence predicted job satisfaction. The predictor variable was idealized influence and dependent variable was job satisfaction. As presented in Table 3, idealized influence explained $24 \%$ of job satisfaction of employees in commercial Banks in Kenya $\left(\mathrm{R}^{2}=.246\right)$

Table 3: Model Summary on Idealized Influence on Job Satisfaction

\begin{tabular}{|c|c|c|c|c|c|c|c|c|c|}
\hline \multirow[b]{2}{*}{ Model } & \multirow[b]{2}{*}{$\mathbf{R}$} & \multirow[b]{2}{*}{$\begin{array}{c}\mathbf{R} \\
\text { Square }\end{array}$} & \multirow[b]{2}{*}{$\begin{array}{l}\text { Adjusted } \\
\text { R Square }\end{array}$} & \multirow{2}{*}{$\begin{array}{c}\text { Std. } \\
\text { Error of } \\
\text { the } \\
\text { Estimate }\end{array}$} & \multicolumn{5}{|c|}{ Change Statistics } \\
\hline & & & & & $\begin{array}{c}\text { R Square } \\
\text { Change }\end{array}$ & $\begin{array}{c}\mathrm{F} \\
\text { Change }\end{array}$ & df1 & df2 & $\begin{array}{c}\text { Sig. F } \\
\text { Change }\end{array}$ \\
\hline 1 & $.496^{\mathrm{a}}$ & .246 & .244 & .93247 & .246 & 112.421 & 1 & 344 & .000 \\
\hline
\end{tabular}

a. Predictors: (Constant), Individualized Influence

The regression ANOVA showed that idealized influence had a significant influence on job satisfaction $\mathrm{F}(1,97.750)=112.421, p<.05)$ as indicated in Table 4. Therefore, the study rejected the null hypothesis $\mathbf{H}_{\mathbf{0 1}}$ : There is no significant influence of idealized influence on job satisfaction among employees in commercial banks in Kenya. 
Human Resource and Leadership Journal

ISSN 2520-4661 (Online)

Vol.3, Issue No.1, p 23 - 46, 2018

$\underline{\text { www.carijournals.org }}$

Table 4: ANOVA Idealized Influence on Job Satisfaction

\begin{tabular}{|l|l|r|r|r|r|r|}
\hline \multicolumn{2}{|l|}{ Model } & Sum of Squares & \multicolumn{1}{c|}{ Df } & Mean Square & \multicolumn{1}{c|}{ F } & \multicolumn{1}{c|}{ Sig. } \\
\hline \multirow{2}{*}{1} & Regression & 97.750 & 1 & 97.750 & 112.421 & $.000^{\mathrm{b}}$ \\
\cline { 2 - 7 } & Residual & 299.108 & 344 & .869 & & \\
\cline { 2 - 7 } & Total & 396.858 & 345 & & & \\
\hline
\end{tabular}

a. Dependent Variable: Job satisfaction

b. Predictors: (Constant), idealized influence

The regression coefficientshowed that idealized influence significantly predicted job satisfaction $(\beta=.676, t(345)=10.603, p<.05)$ as indicated in Table 5.

Table 5: Coefficients of Idealized Influence on Job Satisfaction

\begin{tabular}{|l|l|r|r|r|r|r|}
\hline \multirow{2}{*}{ Model } & \multicolumn{2}{|c|}{$\begin{array}{c}\text { Unstandardized } \\
\text { Coefficients }\end{array}$} & \multicolumn{2}{c|}{$\begin{array}{c}\text { Standardized } \\
\text { Coefficients }\end{array}$} & & \\
\cline { 2 - 7 } & \multicolumn{1}{|c|}{ B } & \multicolumn{1}{c|}{ Std. Error } & \multicolumn{1}{c|}{ Beta } & \multicolumn{1}{c|}{ T } & \multicolumn{1}{c|}{ Sig. } \\
\hline \multirow{2}{*}{1} & (Constant) & .449 & .264 & & 1.702 & .090 \\
\cline { 2 - 7 } & Idealized Influence & .676 & .064 & .496 & 10.603 & .003 \\
\hline
\end{tabular}

a. Dependent Variable: Job satisfaction

Model equation: $\mathrm{Y}=0.449+.676$ (Idealized Influence) +.064

\subsection{Inspirational Motivation}

\subsubsection{Chi-square Test: Inspirational Motivation and Job Satisfaction}

The Chi-square test was conducted to determine whether there was an association between inspirational motivation and job satisfaction. The Chi-square test results showed that inspirational motivation and job satisfaction were strongly associated $\mathrm{X}^{2}(156, \mathrm{~N}=347)=$ $445.180, p<.05)$. This indicated that inspirational motivation was more likely to improve job satisfaction among employees in commercial banks in Kenya.

\subsubsection{Correlation between Inspirational Motivation and Job Satisfaction}

Correlation analysis was used to test the relationship between inspirational motivation and job satisfaction. The results showedthat there was a strong and positive correlation between inspirational motivation and job satisfaction $r(347)=.587, p<.05$. The results are presented in Table 6. 
Human Resource and Leadership Journal

ISSN 2520-4661 (Online)

Journals

Vol.3, Issue No.1, p 23 - 46, 2018

www.carijournals.org

Table 6: Correlation Analysis on Inspirational Motivation and Job Satisfaction

\begin{tabular}{|l|l|l|}
\hline \multicolumn{2}{|c|}{ Inspirational Motivation } & Job Satisfaction \\
\hline & Pearson Correlation & $.587^{* *}$ \\
\cline { 2 - 3 } & Sig. (2-tailed) & .000 \\
\cline { 2 - 3 } & $\mathrm{N}$ & 347 \\
\hline
\end{tabular}

\subsubsection{One Way ANOVA on Inspirational Motivation}

The one way ANOVA test was conducted to test whether there were differences in the mean of inspirational motivation and the demographic information of respondents; gender, age, education level, duration of working at the bank and the tier of the bank. The results indicated there was no significant difference between the mean values of all the respondents' demographic information and inspirational motivation. The results found no significant differences in the mean for inspirational motivation across the managers demographic variables: gender, $F(13,331)=$ $1.349, p<.05$; age, $F(13,330)=.565, p<.05$; education level, $F(13,331)=.787, p<.05$; duration of working, $F(13,332)=.995, p<.05$; and lastly tier of the bank, $F(13,333)=1.528$, $p<.05$.

\subsubsection{Regression Analysis and Hypothesis Testing on Inspirational Motivation}

Regression analysis was conducted to test the hypothesis. The model summary shows how inspirational motivation predicted job satisfaction. The predictor variable was inspirational motivation and dependent variable was job satisfaction. As presented in Table 7(a), inspirational motivation explained $34 \%$ of job satisfaction of employees in commercial banks in Kenya $\left(\mathrm{R}^{2}=\right.$ $.344)$.

Table 7a: Model Summary on Inspirational Motivation on Job Satisfaction

\begin{tabular}{|c|c|c|c|c|c|c|c|c|c|}
\hline \multirow[b]{2}{*}{ odel } & \multirow[b]{2}{*}{$\mathbf{R}$} & \multirow[b]{2}{*}{$\begin{array}{c}\text { R } \\
\text { Square } \\
\end{array}$} & \multirow[b]{2}{*}{\begin{tabular}{|l} 
Adjusted \\
R Square \\
\end{tabular}} & \multirow{2}{*}{\begin{tabular}{|c} 
Std. \\
Error of \\
the \\
Estimate \\
\end{tabular}} & \multicolumn{5}{|c|}{ Change Statistics } \\
\hline & & & & & \begin{tabular}{|c} 
R Square \\
Change
\end{tabular} & $\begin{array}{c}\mathrm{F} \\
\text { Change }\end{array}$ & df1 & df2 & $\begin{array}{c}\text { Sig. F } \\
\text { Change }\end{array}$ \\
\hline 1 & $.587^{\mathrm{a}}$ & .344 & .342 & .83539 & .344 & 180.980 & 1 & 345 & .000 \\
\hline
\end{tabular}

The regression ANOVA showed that inspirational motivation had a significant influence on job satisfaction $F(1,126.302)=180.980, p<.05)$ as indicated in Table 7(b). Therefore the study rejected the null hypothesis $\mathbf{H}_{\mathbf{0 2}}$ : There is no significant influence of inspirational motivation on job satisfaction among employees in commercial Banks in Kenya. 
Human Resource and Leadership Journal

ISSN 2520-4661 (Online)

i Journals

Vol.3, Issue No.1, p 23 - 46, 2018

www.carijournals.org

Table 7b: ANOVA for Inspirational Motivation on Job Satisfaction

\begin{tabular}{|l|l|r|r|r|r|r|}
\hline \multicolumn{2}{|l|}{ Model } & \multicolumn{1}{c|}{$\begin{array}{c}\text { Sum of } \\
\text { Squares }\end{array}$} & Df & Mean Square & \multicolumn{1}{c|}{ F } & Sig. \\
\hline \multirow{2}{*}{1} & Regression & 126.302 & 1 & 126.302 & 180.980 & $.000^{\mathrm{b}}$ \\
\cline { 2 - 7 } & Residual & 240.767 & 345 & .698 & & \\
\cline { 2 - 7 } & Total & 367.069 & 346 & & & \\
\hline
\end{tabular}

a. Dependent Variable: Inspirational motivation on Job Satisfaction

b. Predictors: (Constant), Inspirational motivation

The regression coefficient showed that inspirational motivation significantly predicted job satisfaction $(\beta=.689, t(346)=13.453, p<.05)$ as indicated in Table 8.

Table 8: Coefficients of Inspirational Motivation on Job Satisfaction

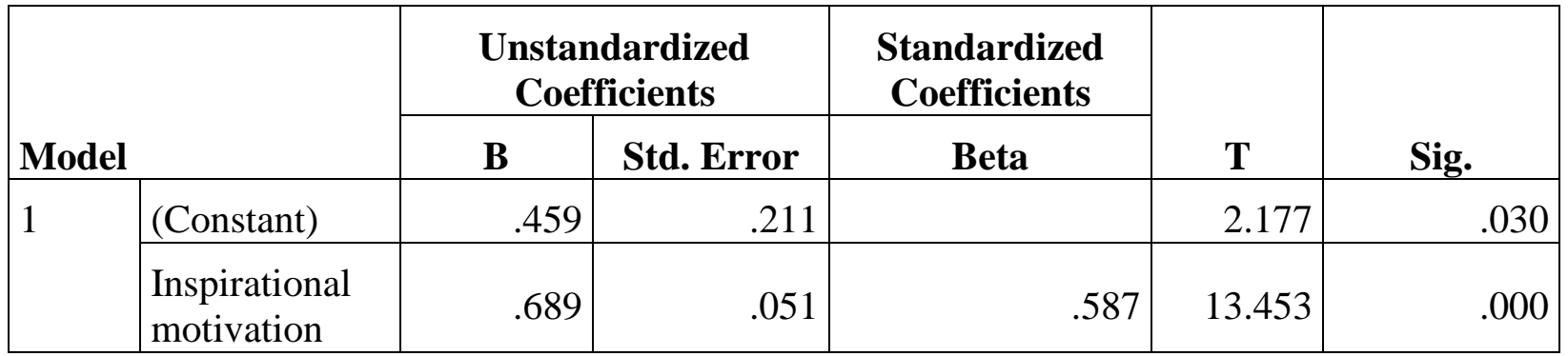

a. Dependent Variable: Inspirational motivation on Job Satisfaction

Model equation: $\mathrm{Y}=0.459+.689$ (Inspirational Motivation) +.051

4.4 Moderating Effect of Job Security on the effect of idealized Influence and Inspirational Motivation on Job Satisfaction

\subsubsection{Chi-square Test: Job Security as Moderating Effect and Job Satisfaction}

The Chi-square test was conducted to determine whether there was an association between job security as moderating effect variable and job satisfaction. The Chi-square test results showed that job security and job satisfaction were strongly associated $\mathrm{X}^{2}(144, \mathrm{~N}=347)=664.814$, $p<.05)$. This indicated that job security was likely to improve job satisfaction among employees in commercial banks in Kenya.

\subsubsection{Correlation between Job Security as Moderating Effect and Job Satisfaction}

Correlation analysis was conducted to test the relationship between job security as the moderating effect and job satisfaction. The results showed there was a strong and positive correlation between job security as moderating effect and job satisfaction $r(347)=.697, p<.05$. The results are as shown in Table 9. 
Human Resource and Leadership Journal

ISSN 2520-4661 (Online)

Vol.3, Issue No.1, p 23 - 46, 2018

www.carijournals.org

Table 9: Correlation Analysis on Job Security as Moderating Effect and Job Satisfaction

\begin{tabular}{|c|c|c|}
\hline \multicolumn{2}{|l|}{ Job security on job satisfaction } & Job Satisfaction \\
\hline \multirow{3}{*}{$\begin{array}{l}\text { Job security as moderating } \\
\text { effect }\end{array}$} & Pearson Correlation & $.697^{* *}$ \\
\hline & Sig. (2-tailed) & .000 \\
\hline & $\mathrm{N}$ & 347 \\
\hline
\end{tabular}

4.4.3 Regression Analysis and Hypothesis Testing on Inspirational Motivation

Multiple linear regression was conducted to test the hypothesis. The model summary showed idealized influence and inspirational motivation explained $35 \%$ of job satisfaction without the inclusion of moderating effect $\left(\mathrm{R}^{2}=.356\right)$. However, with the inclusion of the moderating variable, idealized influence and inspirational motivation explained $43 \%$ of the job satisfaction $\left(\mathrm{R}^{2}=.431\right)$. The results are presented in Table 10 .

Table 10: Model Summary of Inspirational Motivation and Idealized Influenced on Job Satisfaction

\begin{tabular}{|c|c|c|c|c|c|c|c|c|c|}
\hline \multirow[b]{2}{*}{ Model } & \multirow[b]{2}{*}{$\mathbf{R}$} & \multirow[b]{2}{*}{$\begin{array}{c}\mathbf{R} \\
\text { Square }\end{array}$} & \multirow[b]{2}{*}{$\begin{array}{l}\text { Adjusted } \\
\text { R Square }\end{array}$} & \multirow[b]{2}{*}{$\begin{array}{c}\text { Std. Error } \\
\text { of the } \\
\text { Estimate }\end{array}$} & \multicolumn{5}{|c|}{ Change Statistics } \\
\hline & & & & & $\begin{array}{c}\text { R } \\
\text { Square } \\
\text { Change }\end{array}$ & $\begin{array}{c}\mathrm{F} \\
\text { Change }\end{array}$ & df1 & df2 & $\begin{array}{c}\text { Sig. F } \\
\text { Change }\end{array}$ \\
\hline 1 & $.597^{\mathrm{a}}$ & .356 & .353 & .76409 & .356 & 94.931 & 2 & 343 & .000 \\
\hline 2 & $.656^{\mathrm{b}}$ & .431 & .426 & .71948 & .075 & 44.853 & 1 & 342 & .000 \\
\hline
\end{tabular}

The regression ANOVA showed that idealized influence and inspirational motivation had a significant effect on job satisfaction as indicated in Table 11.The study rejected the null hypothesis $\mathrm{H}_{03}$ : There is no significant moderating effect of job security between idealized influence and inspirational motivation and job satisfaction among employees in commercial Banks in Kenya. 
Human Resource and Leadership Journal

ISSN 2520-4661 (Online)

¿ Journals

Vol.3, Issue No.1, p 23 - 46, 2018

$\underline{\text { www.carijournals.org }}$

Table 11: ANOVA on Inspirational Motivation and Idealized Influenced on Job Satisfaction

\begin{tabular}{|l|l|r|r|r|r|r|}
\hline \multicolumn{1}{l}{ Model } & Sum of Squares & \multicolumn{1}{c|}{ df } & Mean Square & \multicolumn{1}{c|}{ F } & Sig. \\
\hline \multirow{2}{*}{1} & 110.847 & 2 & 55.424 & 94.931 & $.000^{\mathrm{b}}$ \\
\cline { 2 - 7 } & Regression & 200.254 & 343 & .584 & & \\
\cline { 2 - 7 } & Residual & 311.101 & 345 & & & \\
\cline { 2 - 7 } 2 & 134.065 & 3 & 44.688 & 86.330 & $.000^{\mathrm{c}}$ \\
\cline { 2 - 6 } & Regression & 177.036 & 342 & .518 & & \\
\cline { 2 - 6 } & Residual & 311.101 & 345 & & & \\
\cline { 2 - 3 } & Total & & & \\
\hline
\end{tabular}

The regression coefficient model showed that both idealized influence and inspirational motivation significantly predicted job satisfaction without the moderating variable. However, with the inclusion of the moderating variable job security, the effect o idealized influence was not significant. Therefore, only inspirational motivation significantly predicted job satisfaction with the moderating effect $(\beta=.289, \mathrm{t}(345)=4.062, p<.05)$. The findings are presented in Table 12.

Table 12: Coefficient on Inspirational Motivation and Idealized Influenced on Job Satisfaction

\begin{tabular}{|c|c|c|c|c|c|c|}
\hline & & \multicolumn{2}{|c|}{$\begin{array}{c}\text { Unstandardized } \\
\text { Coefficients }\end{array}$} & \multirow{2}{*}{$\begin{array}{c}\text { Standardized } \\
\text { Coefficients } \\
\text { Beta } \\
\end{array}$} & \multirow[b]{2}{*}{$\mathbf{T}$} & \multirow[b]{2}{*}{ Sig. } \\
\hline \multicolumn{2}{|c|}{ Model } & B & $\begin{array}{l}\text { Std. } \\
\text { Error }\end{array}$ & & & \\
\hline \multirow[t]{2}{*}{1} & (Constant) & .370 & .223 & & 1.658 & .098 \\
\hline & Idealized Influenced & .186 & .074 & .155 & 2.525 & .012 \\
\hline & Inspirational Motivation & .517 & .066 & .478 & 7.802 & .000 \\
\hline \multirow[t]{4}{*}{2} & $($ Constant $)$ & .415 & .210 & & 1.975 & .049 \\
\hline & Idealized Influenced & .022 & .074 & .018 & .293 & .770 \\
\hline & Inspirational Motivation & .289 & .071 & .267 & 4.062 & .000 \\
\hline & Moderating Variable & .417 & .062 & .422 & 6.697 & .000 \\
\hline
\end{tabular}

Model equation: $\mathrm{Y}=0.415+.289$ (inspirational motivation) +.417 (job security) +.210 
Human Resource and Leadership Journal

ISSN 2520-4661 (Online)

Vol.3, Issue No.1, p 23 - 46, 2018

$\underline{\text { www.carijournals.org }}$

\subsection{DISCUSSIONS, CONCLUSIONS AND RECOMMENDATIONS}

This section presents the discussions, conclusions and recommendations.

\subsection{Discussions}

\subsubsection{Idealized Influenced}

Correlation analysis indicated that idealized influence was positively and significantly correlated to job satisfaction $r(346)=.496, p<.05$. This similar to the findings of Huang, Cheng and Chou (2005) who in their study dubbed 'fitting in organizational values' sought to investigate whether CEO charismatic leadership had a positive effect on employees. The findings demonstrated that charisma did indeed have significant effects on employee outcomes of extra effort, job satisfaction and organizational commitment. The chi-square test was used to determine whether there was a significant association between idealized influence and job satisfaction $X^{2}(132, N=$ $346)=302.886, p<.05)$. Khuong and Hoang (2015) further affirmed this when they found that as much as compensation and fringe benefits matter, the leader's personality and characteristics are more important as they affect the motivational work environment for the staff which in turn yields positive job attitudes. The multiple linear regression results indicated that idealized influence explained $24 \%$ of job satisfaction $\left(\mathrm{R}^{2}=.246, F(1,97.750)=112.421, p<.05\right)$. The analysis showed that idealized influence statistically predicted the value of job satisfaction $(B=$ .676, (.449) $t=10.603, p<.05)$. This is supported by Gitoho, Muchara and Ngugi (2016) on influence of individualized influence on employee satisfaction amongst listed companies in Nairobi securities exchange which found that individualized influence affects job satisfaction. Further, Emu and Umeh (2014) empirically examined the relationship between leadership style and job satisfaction among customer relationship officers in Nigerian banks. The results indicated that idealized influence explained 24\% of job satisfaction. The low degree of influence (24\%) was similar to what Long, Yusuf, Kowang and Heng (2014) found in their study 'impact of transformational leadership on job satisfaction in Malaysia'. Results of the study revealed a positive but non-significant relationship between idealized influence and job satisfaction.

\subsubsection{Inspirational Motivation}

Correlation analysis indicated that inspirational motivation was positively and significantly correlated to job satisfaction $r(347)=.587, p<.05$. This is in agreement with Rizwan et al. (2012) who did an empirical study of employee job satisfaction and aimed at establishing the crucial problems faced by employees and finding ways to enhance employee loyalty. Findings point to a strong and positive relationship between inspirational motivation aspects and job satisfaction. The chi-square test was used to determine whether there was a significant association between inspirational motivation and job satisfaction $\left.\mathrm{X}^{2}(156, \mathrm{~N}=347)=445.180, p<.05\right)$. Thus, the supervisor's role on inspirational motivation cannot be overemphasized on the significant impact it has on job satisfaction (Kakakhel et al., 2015) The multiple linear regression results indicated that inspirational motivation explained $34 \%$ of job satisfaction $\left(\mathrm{R}^{2}=.344, \mathrm{~F}(1,126.302)=\right.$ $180.980, p<.05)$. The analysis showed inspirational motivation statistically predicted the value of job satisfaction $(B=.689$, (2.117) $t=13.453, p<.05)$. Akipinar et al. (2013) in their study proffered that job satisfaction was a result of organizational commitment and not organizational communication. 
Human Resource and Leadership Journal

ISSN 2520-4661 (Online)

Vol.3, Issue No.1, p 23 - 46, 2018

$\underline{\text { www.carijournals.org }}$

The results indicated that there was a positive relationship between employee's perception of organizational communication and organizational commitment. However, unlike many studies, the results indicated communication to a greater extent predicted organizational commitment as opposed to job satisfaction. Shujaat et al. (2014) conducted a research to establish the impact of team work on employee job satisfaction. Results of the study indicated there was a significant impact between team work and job satisfaction. This goes on to indicate that it is important for organizational leaders to build a team work culture, build team skills and hold it in high regard because of its significant effect on job satisfaction and achieving organizational goals. Additionally, Rana (2015) went out to determine the job satisfaction factors affecting employees in the Bangladesh banking sector. The results indicated that there was a significant and positive relationship between human resource management practices like team work, job autonomy and leadership behaviour on job satisfaction; however, team work was the most important factor affecting job satisfaction

\subsubsection{Job Security as Moderating}

There was positive correlation on moderating effect and job security $r(347)=.697, p<.05$. Studies have found the elements of job security to be strong predictors of job satisfaction and thus a leader should endeavor to reassure his employees through effective and accurate communication to dispel any anxieties ensuring fairness to all (Kler et al., 2015). The chi-square test was used to determine whether there was a significant association between job security as moderating effect variable and job satisfaction $\left.X^{2}(144, \mathrm{~N}=347)=664.814, p<.05\right)$. Thorsteinsson, Brown and Richards (2014) examined the association between stress, organizational support and staff health which incorporated anxiety, depression and fatigue together with work outcomes like turnover intentions, organizational commitment and job satisfaction. Their findings indicated that high work stress was associated with worse staff health like anxiety, depression and fatigue all of which lead to negative work outcomes. The multiple linear regression idealized influence and inspirational motivation explained $35 \%$ of the job satisfaction without the inclusion of moderating effect $\left(\mathrm{R}^{2}=.356, F(2,55.42)=94.931, p<.05\right)$ while the remaining $65 \%$ of job satisfaction was explained by other factors. But with the inclusion of the moderating variables, idealized influence and inspirational motivation explained $43 \%$ of the job satisfaction $\left(\mathrm{R}^{2}=.431, F(3,44.688)=86.330, p<.05\right)$ while the remaining $57 \%$ of job satisfaction was explained by other factors. This showed with the inclusion of moderating effect, idealized influence and inspirational motivation variables predicted job satisfaction with more accuracy; thus job security is a key factor in determining job satisfaction. Studies have revealed that lack of job security has consequences among them turnover intentions which consequently affect job satisfaction. These results are in line with results of other studies which have found that job security is a key factor that influences the employee's perception of job satisfaction (Alonderiene \& Majauskaite, 2016). According to Islam and Zaman2 (2013), job security provides employees with job satisfaction which ultimately has an impact on their levels of motivation and productivity. Khan et al. (2013) conducted research on whether job satisfaction of operational staff in Islamic Banks was determined through organizational climate, occupational stress, age and gender. 
Human Resource and Leadership Journal

ISSN 2520-4661 (Online)

Vol.3, Issue No.1, p 23 - 46, 2018

www.carijournals.org

The results revealed that organizational climate and occupational stress have a significant impact on level of job satisfaction. These search findings supports the research result that job security influences job satisfaction.

\subsection{Conclusion}

Multiple linear regression analysis results showed that idealized influence explained $24 \%$ of job satisfaction $(\mathrm{R} 2=.246, \mathrm{~F}(1,97.750)=112.421, \mathrm{p}<.05)$ and predicted job satisfaction. As a result, the null hypothesis that there was no significant influence of idealized influence on job satisfaction among employees in commercial Banks in Kenya was rejected.

Multiple linear regression analysis results showed that inspirational motivation explained $34 \%$ of job satisfaction $(\mathrm{R} 2=.344, \mathrm{~F}(1,126.302)=180.980, \mathrm{p}<.05)$. As a result, the null hypothesis that there was no significant influence of inspirational motivation on job satisfaction among employees in commercial Banks in Kenya was rejected. The study concluded that inspirational motivation influenced job satisfaction among employees in commercial Banks in Kenya.

Multiple linear regression analysis results showed that the moderating effect of job security between idealized influence and inspirational motivation explained $43 \%$ of the job satisfaction $\left(\mathrm{R}^{2}=.431, F(3,44.688)=86.330, p<.05\right)$. Therefore, the null hypothesis that there was no significant influence of job security between idealized influence and inspirational motivation on job security was rejected.

\subsection{Recommendations}

The findings of this study indicated that idealized influence and inspirational motivation positively influenced and significantly predicted job satisfaction among employees in commercial Banks in Kenya. The moderating effect of job security also had a significant influence on the relationship between idealized influence, inspirational motivation and job satisfaction. Therefore, leaders in the commercial Banks should leverage on idealized influence and inspirational motivation to drive job satisfaction. Additionally, they should ensure employees feel they have job security because it has a significant influence on job satisfaction.

\subsection{Recommendations for Further Studies}

This study focused on the influence of transformational leadership style on job satisfaction among employees in commercial banks in Kenya. During the study, some employees observed that transactional leadership theory also influence job satisfaction because of the perceived exchange for example where there were good bonus schemes. Therefore, future studies could focus on the influence of transactional leadership theory on job satisfaction among employees in commercial banks in Kenya. 
Human Resource and Leadership Journal

ISSN 2520-4661 (Online)

Vol.3, Issue No.1, p 23 - 46, 2018

$\underline{\text { www.carijournals.org }}$

\section{REFERENCES}

Abouraia, M.K. \& Othman, S.M. (2017). Transformational Leadership, Job Satisfaction, Organizational Commitment, and Turnover Intentions: The Direct Effects among Bank Representatives, American Journal of Industrial and Business Management, 2017, 7, 404-423

Ahmed, B., Shad, I., Mumtaz, R. \& Tanveer, Z. (2012). Organizational ethics and job satisfaction: Evidence from Pakistan, African Journal of Business Management, Vol. 6(8), pp. 2966-2973

Akotch, W.F. \& Munyoki, J. (2016). Determinants of growth in the banking industry in Kenya, African Journal of Marketing Management, Vol. 8(1), pp. 1-11

Akpan, C.P. (2013). Job security and job satisfaction as determinants of organizational commitment among university teachers in cross river state, Nigeria, British Journal of Education, Vol.1, No.2, pp. 82-93

Akpinar, A.T., Torun, E., Okur, M.E. \& Akpinar, O. (2013). The Effect of Organizational Communication and Job Satisfaction on Organizational Commitment in Small Businesses, Interdisciplinary Journal of Research in Business, Vol.3, Issue. 0, pp. 27-32

Alonderiene, R., \& Majauskaite, M. (2016). Leadership style and job satisfaction in higher education institutions, International Journal of Educational Management, Vol. 30 Iss: 1, pp. $140-164$

Arif, A \& Anees, A.N. (2012),Liquidity risk and performance of banking system, Journal of Financial Regulation and Compliance, Vol. 20 Iss 2 pp. $182-195$

Aswathi, R. (2015). Relationship between ethical atmosphere at workplace and job satisfaction, Asian Journal Of Management Research 35, Volume 6 Issue 1,

Avolio, B.J. \&. Bass B.M. (2002). Developing Potential Across a Full Range of Leadership. Mahwah, NJ: Lawrence Erlbaum Associates,

Bass, B. M. (1985). Leadership and performance beyond expectation. New York: Free Press.

Belias, D \& Koustelios, A. (2014). Transformational Leadership and Job Satisfaction in the Banking Sector: A Review, International Review of Management and Marketing, Vol. 4, No. 3, 2014, pp.187-200

Bell, R.M. (2013). Charismatic Leadership Case Study with Ronald Reagan as Exemplar, Emerging Leadership Journeys, Vol.65 Iss. 1, pp. 83- 91

Benrazavi, S.R. \& Silong, A.D. (2013). Employees' Job Satisfaction and Its Influence on Willingness to Work in Teams, Journal of Management Policy and Practice, vol. 14(1)

Brandt, T., Laitinen, E \& Laitinen, T (2016), The effect of transformational leadership on the profitability of Finnish firms , International Journal of Organizational Analysis, Vol. 24 Iss 1 pp. $81-106$ 
Human Resource and Leadership Journal

ISSN 2520-4661 (Online)

Vol.3, Issue No.1, p 23 - 46, 2018

$\underline{\text { www.carijournals.org }}$

Burns, J.M. (1978). Leadership. New York. Harper \& Row

Chatterjee, I. \& Chattopadhyay, M. (2015). The impact of motivational factors on job satisfaction of public and private sector bank employees, International Journal of Science Technology and Management, Vol.4, special issue no.01

Dinc, M.S. \& Aydemir, M. (2014). The Effects of Ethical Climate and Ethical Leadership on Employee Attitudes: Bosnian Case, International Journal of Management Sciences, Vol.2, No.9, 391-405

Emu, K.E. \& Umeh, O.J., (2014). How Leadership Practices Impact Job Satisfaction of Customer Relationship Officers': An Empirical Study. Journal of Management Policies and Practices, 2 (3), 19-56.

Gitoho, W. S., Muchara, M., \& Ngugi, J.K., (2016). Influence of Transformational Leadership Style on Employee Job Satisfaction: Case Study of Firms Listed at the NSE. International Journal of Novel Research in Marketing Management and Economics, 3 (2), 177-190.

Hanaysha, J.R.M., Khalid, K., Kamariah N. N. M., Sarassina, F., Ab Rahman, M.Y.B., Bin \& Zakaria, A.S. (2012). Transformational Leadership and Job Satisfaction American Journal of Economics, American Journal of Economics, Special Issue: $\quad$ 145-148

Huang, M., Cheng, B \& Chou, L. (2005),Fitting in organizational values, International Journal of Manpower, Vol. 26 Iss 1 pp. 35 - 49

Hurduzeu, R.E. (2015). The Impact of Leadership on Organizational Performance, SEA Practical Application of Science, 2015, Issue 7, 289-294

Imran, R., Majeed, M., \& Ayub, A., (2015). Impact of Organizational Justice, Job Security and Job satisfaction on Organizational Productivity, Journal of Economics, Business and Management, 3 (9), 840-845.

Intentions: An Empirical Study, East West Journal of Business and Social Studies, Vol.3

Iqbal, N., Bhatti, W.A. \& Zaheer, A. (2013). Corporate ethical values, Group creativity, Job commitment And performance: The effect of work Response on work context, Management \& Marketing

Islam, K.M.A. \& Zaman2, M. (2013). Job satisfaction \& bankers turnover: a case study on Bangladesh commerce bank limited, International Journal of Business and Management Review, Vol. 1 No. 4, pp. 1-14.

Kakakhel, S.J., Khan, A., Gul, S. \& Jehangir, M. (2015). Impact of Organizational Communication on Organization Commitment and Job Satisfaction: Assessing the Moderating role of Physical Work Environment, Journal of Applied Environmental and Biological Sciences, 5(12)313-321

Kelly, T., Lercel, D. \& Patankar, M. (2015). Influence of Trust and Job Satisfaction on Safety Climate among Managers at a Large U.S. Air Carrier, Management and Organizational Studies, Vol. 2, No. 2 
Human Resource and Leadership Journal

ISSN 2520-4661 (Online)

Vol.3, Issue No.1, p 23 - 46, 2018

$\underline{\text { www.carijournals.org }}$

Khan, A., Ramzan, M., \& Butt, S. M. (2013). Is job satisfaction of Islamic banks operational staff determined through organizational climate, occupational stress, age and gender, Journal of Business Studies Quarterly, 4(3), 13-26

Khuong, M.N. \& Hoang, D.T. (2015). The Effects of Leadership Styles on Employee Motivation in Auditing Companies in Ho Chi Minh City, Vietnam, International Journal of Trade, Economics and Finance, Vol. 6, No. 4

Kler, P., Leeves, G. \& Shankar, S. (2015). Nothing to Fear but Fear Itself: Perceptions of Job Security in Australia After the Global Financial Crisis, Soc Indic Res, 123:753-769

Lin, A.W., Bahron, A. \& Boroh, R.P. (2014). A Study on Role Stress and Job Satisfaction among Bank Employees in Kota Kinabalu, Sabah, International Journal of Research in Management \& Business Studies, Vol.1, Issue 2

Long, C. S.,Yusuf, W.M., Kowang, T.O., \& Heng, L.H. (2014). The Impact of Transformational Leadership Style on Job Satisfaction, World Applied Sciences Journal 29 (1): 117-124

Malik, W.U., Javed, M. \& Hassan, S.T. (2017). Influence of Transformational Leadership Components on Job Satisfaction and Organizational Commitment, Pakistan Journalof Commerce and Social Sciences, Vol. 11 (1), 146-165

Manzoor, S.R., Ullah, H., Hussain, M. \& Ahmad, Z.M. (2011). Effect of Teamwork on Employee Performance, International Journal of Learning \& Development, Vol.1, No.1

Mincu, C.L. (2015). The Impact of Personal Resources on Organizational Attitudes: Job Satisfaction and Trust in Organization, Procedia - Social and Behavioral Science, Vol.187, Pages 685-689

Muenjohn, N. (2010). Transformational Leadership: A New Force In Leadership Research,School of Management, RMIT University, Australia

Munir, R., Baird, K., \& Perera, S. (2013),Performance measurement system change in an emerging economy bank, Accounting, Auditing \& Accountability Journal, Vol. 26 Iss 2 pp. $196-233$

Munir, R.I.S., Rahman, R.A., Malik, A.M.B. \& Ma'amor, H. (2012). Relationship between transformational leadership and employee's job satisfaction among the academic staff, International

Ngaithe, L., K'Aol, G., Lewa, P., \& Ndwiga, M., (2016). Effect of Idealized Influence and Inspirational Motivation on Staff Performance in State Owned Enterprises in Kenya. European Journal of Business and Management, 8(30).

Njuguna, S.G. \& Owuor, E. (2016). Factors Affecting Employee Satisfaction in the Banking Industry: Case of Consolidated Bank of Kenya Limited, Kenya, European Journal of Business and Strategic Management, Vol.1, Issue 1 No.1, pp 51-69

Omar W.A.W. \& Hussin, F. (2013). Transformational Leadership Style and Job Satisfaction Relationship: A Study of Structural Equation Modeling (SEM), International Journal of Academic Research in Business and Social Sciences, Vol. 3, No. 2 
Human Resource and Leadership Journal

ISSN 2520-4661 (Online)

Vol.3, Issue No.1, p 23 - 46, 2018

$\underline{\text { www.carijournals.org }}$

Osakwe, R.N. (2014). Factors Affecting Motivation and Job Satisfaction of Academic Staff of Universities in South-South Geopolitical Zone of Nigeria, International Education Studies, Vol. 7, No. 7

Patiar, A., \& Wang, Y. (2016). The effects of transformational leadership and organizational commitment on hotel departmental performance. International Journal of Contemporary Hospitality Management, 28(3), 586-608

Pettijohn, C., Pettijohn, L. and Taylor, A.J. (2008), Salesperson perceptions of ethical behaviors: their influence on job satisfaction and turnover intentions, Journal of Business Ethics, Vol. 78 No. 4, pp. 547-557

Poursadeghiyan, M., Abbasi, M., Mehri, A., Hami, M., Raei, M. \& Ebrahimi, H. (2016). Relationship between job stress and anxiety, depression and job satisfaction in nurses in Iran,The social sciences, 11 (9)

Rai, G.S. (2013). Impact of organizational justice on satisfaction, commitment and turnover intention: Can fair treatment by organizations make a difference in their workers' attitudes and behaviors? International Journal of Human Sciences, Vol.10, Iss 2

Rajan, D. (2015). Motivation and job satisfaction: a study of pharmacists in private hospitals, Samvad, Vol.9

Rana, S.(2015). Job Satisfaction Effecting Factors of Employees in Bangladesh Banking Sector, International Journal of Economics, Finance and Management Sciences, 3(4): 352-357

Rizwan, M., Khan, W.M., Tarig, H.M.A., Ghaffar, A., Anjum, M.Z. \& Bajwa, E.U. (2012). Empirical study of Employee job satisfaction, Journal of Business Management, 29-35

Sattar, S. \& Ahmed, S., (2014). Factors effecting employee turnover in banking sector: empirical evidence. Developing country studies, vol. 4(3), pp. 110-115.

Shujaat, S., Manzoor, A. \& Syed, N.A. (2014). Impact of Team Work on Employee Satisfaction, IBT Journal of Business Studies, Vol.10,No.2,71-80

Susanj, Z. \& Jakopec, A. (2012). Fairness Perceptions and Job Satisfaction as Mediators of the Relationship between Leadership Style and Organizational Commitment, Pscychological Topics,3,509-526

Tetteh, E.N. and Brenyah, R.S., 2016. Organizational leadership styles and their impact on employee's ob satisfaction: evidence from the mobile telecommunications sector of Ghana. Global Journal of Human Resource Management, 4(4), pp.12-24.

Thorsteinsson, E.B., Brown, R.F \& Richards, C. (2014). The Relationship between Work-Stress, Psychological Stress and Staff Health and Work Outcomes in Office Workers, Scientific Research Publishing Inc.

Trmal, S.A., Bustamam, U.S.A. \& Mohamed, Z.A. (2015). The Effect of Transformational Leadership in Achieving High Performance Workforce That Exceeds Organisational Expectation: A Study from a Global and Islamic Perspective, Global Business and Management Research: An International Journal, Vol. 7, No. 2 
Human Resource and Leadership Journal

ISSN 2520-4661 (Online)

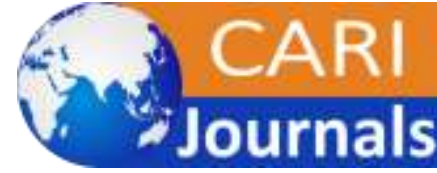

Vol.3, Issue No.1, p 23 - 46, 2018

Usikalu, O., Ogunleye, A.J. \& Effiong, J. (2015). Organizational Trust, Job Satisfaction and Job Performance Among Teachers in Ekiti State, Nigeria, British Open Journal of Psychology, Vol. 1, No. 1, pp. 1- 10

Winska, J. (2010). Influence of superior subordinate communication on employee satisfaction, Journal of Positive Management, Vol.1, No.1, pp.110-124

Zalewska, A.M. (2011). Relationships between anxiety and job satisfaction - Three approaches: 'Bottom-up', 'top-down' and 'transactional' Personality and Individual Differences, 50, 977-986 